\title{
Interferon Lambda-1
}

National Cancer Institute

\section{Source}

National Cancer Institute. Interferon Lambda-1. NCI Thesaurus. Code C104352.

Interferon lambda-1 (200 aa, $22 \mathrm{kDa}$ ) is encoded by the human IFNL1 gene. This protein plays a role in both cytokine signaling and the response to viral infection. 